\title{
IS THERE AN ITALIAN CONCEPTION OF INTERNATIONAL LAW?
}

\author{
Francesco Messineo ${ }^{*}$
}

\begin{abstract}
In 1943, Angelo Piero Sereni wrote The Italian Conception of International Law, a book explicitly aimed at restoring Anglo-American respect for Italian international lawyers after the Fascist period. On the seventieth anniversary of the publication of this work, it is worth considering whether there is, in fact, such a thing as an 'Italian' conception of international law. Methodologically speaking, does thinking of international law in terms of national schools make sense? Although a comparative approach to international law is back in vogue, this article questions the validity of any attempt at finding any 'Italian distinctiveness' in the intellectual history of the Italian school(s) of international law. Sereni's enlisting of ancient masters to an 'Italian' conception between the 13th and 18th centuries is for the most part untenable. While a distinctively Italian conception of international law arguably came into existence in the 19th century with Mancini's theory of nationalities, Anzilotti successfully set out to dissolve this into the 20th century European mainstream of positivist international law. The ensuing absence of an 'Italian' conception may give pause for thought to contemporary proponents of 'comparative international law'
\end{abstract}

\section{Keywords}

Comparative international law, Italy, history of international law, legal positivism, natural law, Fascism, Marxism, Catholicism, Alberico Gentili, Pasquale Mancini, Dionisio Anzilotti, Roberto Ago, Angelo Piero Sereni.

\section{Introduction}

A 'comparative' approach to international law is back in vogue these days, slowly re-emerging from the near-fatal blow dealt to it by the demise of 'Soviet

\footnotetext{
Dott. giur. (Catania), LL.M., Ph.D. (Cambridge); Lecturer in Law, Kent Law School, Canterbury <F.Messineo@kent.ac.uk>. Many thanks to Denis Alland, Paolo Amorosa, Giulio Bartolini, Michael Becker, Oriana Calvo, Gabriella Carella, Federica Cittadino, Judge Giorgio Gaja, Christina Hoss, Viktorija Jakimovska, Martti Koskenniemi, Luigi Nuzzo, Antoine Ollivier, Federica Paddeu, Paolo Palchetti, Ioanna Pervou, Walter Rech, Cecily Rose, Francesco Salerno, Cristina Villarino-Villa, and Judge Abdulqawi Ahmed Yusuf for their precious comments on previous drafts, as well as to Lisa Gagliano and Stefano Messineo for bibliographic assistance. All the usual disclaimers apply.
}

Copyright $\odot$ the Author(s).

This work is licensed under a Creative Commons Attribution-NonCommercial-NoDerivs 3.0 License. 
international law.' Many authors are once again investigating the impact of national legal traditions in the construction of international law, but Italy has so far been rather neglected. ${ }^{2}$ For instance, consider Martti Koskenniemi's recent claim that international law is a "German discipline" in a way that it cannot be said to be "French", "British" or indeed an "American" discipline.' He did not even mention the Italian school in his analysis, let alone include it as one of the possible alternatives to the pervasive German influence. True, he affirmed that international law is, in the eyes of many, a sort of 'European political vocabulary'. But this was a rather truncated Europe, as far away from the Mediterranean Sea as Mitteleuropa and the Danube can be. Italy was also conspicuously absent from the recent Oxford Handbook of the History of International Law, with the exception of a few pages on the Oxonian scholar Alberico Gentili and a handful of references to other authors. ${ }^{5}$

At the other end of the spectrum, Angelo Piero Sereni claimed in his 1943 book, The Italian Conception of International Law, that modern international law was essentially Italian. The complex relations between the independent or semiindependent comuni during the Renaissance period were, in his view, a springboard for future European-wide transformations which created international law as we know it today. ${ }^{6}$ Also, he argued, it was Gentili, not Grotius, the 'realistic and passionate' man who employed 'juridical precision' to solve the 'urgent problems of his times', unencumbered by the 'tedious ... abuse of quotations' which is found in Grotius; ${ }^{7}$ and while it was silly to argue over who the real 'father' of

1 On the term 'comparative international law' and its Cold War legacy, see B N Mamlyuk \& U Mattei, 'Comparative International Law', (2011) 36 Brook J Int'l L 385; W E Butler, 'Comparative approaches to international law', (1985) $190 R d C$ 9. For a contemporary (and far more doctrinal) understanding, see A Roberts, 'Comparative International Law? The Role of National Courts in International Law’, (2011) 60(1) ICLQ 57.

2 Except by Italian scholars themselves: see e.g. F Salerno, 'La Rivista e gli studi di diritto internazionale nel periodo 1906-1943', (2007) 90(2) Riv Dir Int 305; P Ziccardi, 'Evoluzione e traguardi della scuola italiana di Diritto internazionale nel XX secolo', in F M Mariño Menéndez (ed) El Derecho internacional en los albores del siglo XXI: homenaje al profesor Juan Manuel Castro-Rial Canosa (2002) 715; E Cannizzaro, 'La doctrine italienne et le développement du droit international dans l'après-Guerre: entre continuité et discontinuité, (2004) 50 AFDI 1.

3 M Koskenniemi, 'Between Coordination and Constitution: International Law as a German Discipline', (2011) 15 Redescriptions. Yearbook of Political Thought, Conceptual History and Feminist Theory 45, 45.

4 Ibid.

5 B Fassbender \& A Peters (eds), The Oxford Handbook of the History of International Law (2012). In contrast, the book contains contributions by Italian scholars.

6 A P Sereni, The Italian Conception of International Law (1943), 118-22.

7 Ibid, 116. 
international law was, or indeed to dwell on Gentili's superiority or older age, the two authors could certainly be deemed equal. They were the product of the same 'epoch, theories and historical problems.'

My intention here is not to defend the Italian school of international law from unwarranted obliteration at the hands of Northern European scholars. As we shall see, international legal academia is alive and well in Italy-its scholarly production needs no advocates, only keen readers. My aim is rather to critically revisit Sereni's book seventy years after its publication.

Can we really identify an 'Italian' conception of international law? And even if such 'Italian' conception existed, would it be radically different from, say, the 'German', 'French' or 'British' conceptions? After all, legal historians such as Paolo Grossi would probably argue that all of these national schools, in fact, belong to the same European legal order, their differences merely variants of the same 'modern legal myths' feeding legal positivism. ${ }^{9}$ The broader methodological question underlying this article is whether attempts to separate schools of international law according to nationality really advance our understanding of the discipline. Can the influence of different legal traditions in international law really be fruitfully understood in terms of 'comparative international law'?

\section{An 'Italian school' obviously exists}

In the broadest sense of the word 'school' (a group of academics engaged in the study of a certain area of human knowledge), there is no doubt that an Italian school of international law exists. A relatively high number of Italians have always featured prominently in the relevant professional circles. We can count five Italian judges at the World Court (Anzilotti at the Permanent Court of International Justice, which he also presided; Morelli, Ago, Ferrari Bravo and Gaja at the International Court of Justice); one judge at the International Tribunal for the Law of the Sea (Treves); one member of the Appellate Body of the World Trade Organisation (Sacerdoti); three judges at the International Criminal Tribunal for the Former Yugoslavia (Cassese, who also presided it, Pocar, Lattanzi as judge ad litem); one judge ad litem at the International Criminal Tribunal for Rwanda (Lattanzi); two judges at the International Criminal Court (Politi and the current Vice President, Tarfusser); many counsel appearing before the International Court of Justice (nine of them appearing between 1999 and

\footnotetext{
${ }^{8}$ Ibid, 115-7.

9 P Grossi, Mitologie giuridiche della modernità (3rd edn, 2007).
} 
2012); and of course a constant (if automatic) presence at the European Court of Human Rights (including Balladore Pallieri, who presided it in the 1970s) and at the European Court of Justice.

Moreover, an Italian was the first President of the Institut de droit international, Pasquale Stanislao Mancini. As we shall see, he was a Risorgimento man with eclectic interests spanning from poetry to politics, although he did not disdain some old-fashioned nepotism, having sponsored his son-in-law Augusto Pierantoni to join the Institut at its foundation in 1873. Since then, Italians have always been conspicuously present at the Institut (the current list of Italian members amounts to about a dozen). For its part, the UN-established International Law Commission has had four Italian members since 1957 (Ago, Arangio-Ruiz, Ferrari Bravo and Gaja).

Italian scholars have featured even more prominently at the Hague Academy of International Law. The Academy's summer courses started in 1923 and have since been an excellent indicator of who constitutes the 'Invisible College' of international lawyers. ${ }^{10}$ Of the 1300 published courses given at the Academy since its opening, around 10 per cent were given by 81 Italian scholars. In total, 69 out of the 83 summer sessions held so far have had at least one Italian scholar as a teacher. Furthermore, Italians gave 10 of the Academy's 'general courses' in public international law (Cavaglieri in 1929, Salvioli in 1933, Morelli in 1956, Quadri in 1964, Ago in 1974, Monaco in 1968, Conforti in 1988, Capotorti in 1994, Condorelli in 2010, Gaja in 2011) and four of the 'general courses' in private international law (Ago in 1936, Vitta in 1979, Pocar in 1993, Picone in 1999). These are regarded as important signs of international recognition in the field of international law. Interestingly, at the Academy, Italians taught mainly in French (114 out of 130 courses). In fact, Italians taught only in French until 1959, when Sereni was the first Italian to give a course in English.

Quite tellingly, of the prominent Italian international lawyers considered above, only three are women: Judge Lattanzi; Loretta Malintoppi, a counsel who appeared before the International Court of Justice; and Boschiero, the only woman, among the 81 Italians, who has taught at the Hague Academy of International Law. These numbers do not quite reflect the important contribution of many other female Italian scholars to international law; rather, they confirm the existence of wider diversity issues at the top of the profession, both in Italian academia and in international law more generally. ${ }^{11}$

\footnotetext{
${ }^{10}$ For the term 'Invisible college', see O Schachter, 'The Invisible College of International Lawyers', (1977-1978) 72 Nw U L Rev 217.

${ }^{11}$ See e.g. the important empirical study conducted by C Rose \& S Kumar, 'Diversity and the Field
} 
According to the latest figures, ${ }^{12}$ there are at least 268 scholars in public and private international law employed by Italian universities, plus at least 70 academics specialising in European Union law. ${ }^{13}$ The reasons for these high numbers are structural. As many as 71 Italian universities currently conduct teaching and research in law. ${ }^{14}$ Of these, the vast majority are state universities, whose law schools usually have no entry selection, and as such, student numbers are very high compared to more selective higher education systems. Because the study of international law is compulsory for most students undertaking a law degree, and because of additional international law teaching needs at other faculties (political science, economics), many universities employ more than one chair in international law and a few associate professors and researchers. Furthermore, a number of prominent law review journals and yearbooks are based in Italy, such as the Rivista di diritto internazionale (established in 1906); La Comunità Internazionale; the Comunicazioni e Studi dell'Istituto di Diritto Internazionale e Straniero della Università di Milano; the Rivista di diritto internazionale privato e processuale (focusing on private international law); and the Italian Yearbook of International Law, catering for an international audience. The Journal of International Criminal Justice was founded by Cassese and is still managed by an Italian scholar, while the European Journal of International Law has consistently had a number Italian editors and contributors. Italians regularly publish articles in other English and French language journals. But is their work any good? During the latest Research Quality Assessment conducted nationally (VQR 2004-2010), fellow academics anonymously reviewed selected writings by international lawyers based at Italian universities and found that 57.1 per cent of the reviewed outputs were either 'good' or 'excellent', 21.6 per cent were 'acceptable', and 21.3 per cent were of 'limited' value or worse. Although not outstanding, these figures were better than the national average for law subjects, perhaps confirming the suspicion that Italians are rather harsh markers. ${ }^{15}$

of Public International Law: A Study of the Nationality and Gender of Counsel Appearing Before the ICJ', working paper presented at the European Society of International Law research forum, Amsterdam, 24 May 2013, on file with author.

${ }^{12}$ See Agenzia Nazionale di Valutazione del sistema Universitario e della Ricerca, 'Valutazione della Qualità della Ricerca 2004-2010 (VQR 2004-2010)', Rapporto Finale, 30 June 2013, <http://www.anvur.org/rapporto/> [accessed 23 July 2013].

${ }^{13}$ The increase in the last 30 years has been quite marked: Antonio Cassese had counted 131 scholars in the late 1980s: A Cassese, 'Capitolo terzo - diritto internazionale', in L Bonanate (ed) Studi internazionali (1990) 113, 115-6.

${ }^{14}$ See above $n 12$.

${ }^{15}$ Ibid. 
In sum, international law scholarship is alive and well in Italy, as testified inter alia by the activities of the Società Italiana di Diritto Internazionale, the learned society of the profession. But can we identify a distinctively 'Italian' conception of international law in this multifarious production?

\section{An 'Italian conception' may not exist}

\subsection{Renaissance Italy as a laboratory of international legal practice}

While any attempt to appropriate the heritage of the whole Roman Empire on behalf of Italy would, in fact, be ludicrous, it must be conceded that 'Italy' was born well before the Italian state was established in 1861. An intellectual history of 'Italian' international legal thinking would thus need to start somewhere near the creation of an 'Italian' language and culture (as opposed to a 'Latin' one)-perhaps in the late $13^{\text {th }}$ century, when Sicilian poets at the court of Frederick II influenced Tuscan writers such as Dante, Petrarch and Boccaccio in laying the literary foundations of Italian culture, sonnet by sonnet, unrequited love by unrequited love. Dante was also-some would say chiefly-a political writer, and his De Monarchia can indeed be explored in search of insights on the organisation of a world legal order. ${ }^{16}$ Obviously, one would need to consider the international dimension of later developments in the history of Italian political thought, such as Machiavelli's Principe. ${ }^{17}$ In Sereni's view, however, these were not legal writers. Sereni's history of Italian international legal doctrine begins with the $14^{\text {th }}$ century's jurist par excellence, Bartolus of Sassoferrato. ${ }^{18}$

In enlisting Bartolus to public international law, Sereni is forced to stretch reality slightly. Possibly the most noteworthy commentator of the Corpus Iuris Civilis, Bartolus is known to international lawyers for his treatise on reprisals ${ }^{19}$ and for what is often considered the first work on private international law. ${ }^{20}$ So far, so good. However, Sereni tries to persuade his readers that Bartolus was also a public international law theorist, because of his work concerning the

\footnotetext{
${ }^{16}$ Hans Kelsen's first book was on Dante: H Kelsen, Die Staatslehre des Dante Alighieri (1905). See also M Koskenniemi, “International community” from Dante to Vattel', in V Chetail \& P Haggenmacher (eds), Vattel's International Law in a XXIst Century Perspective (2011) 51, 54-6.

${ }^{17}$ Koskenniemi, above n 16, 56-7.

${ }^{18}$ Sereni, above n 6, 58.

${ }^{19}$ Bartolus of Sassoferrato, Tractatus represaliarum (1354).

${ }^{20}$ See J H Beale (ed), Bartolus on the Conflict of Laws (1914).
} 
relationship between Italian cities. In Sereni's view, the semi-independent cities of Italian Renaissance were precursors of modern states, because the concept of superiorem non recognoscentes, at the basis of a modern conception of sovereignty, was conceived of at the time.

The last remaining vestiges of the Holy Roman Empire could be equated to today's international community-a system of coordination of sovereign entities, rather than a superior authority. ${ }^{21}$ Sereni even affirms, in no uncertain terms, that 'the modern international society is but the same empire transformed and amplified' 22 and that the international community of today is ... the ancient civitas Christiana, which united all the peoples of Europe in one organism under the supreme authority of the emperor and the pope. ${ }^{23}$ The civitas was gone, but the international community remained. In this regard, Sereni quoted approvingly from Giorgio Balladore Pallieri (1905-1980), according to whom the end of 'imperial and papal authority' had not destroyed 'the general juridical order that centered in these powers. ${ }^{24}$ The rules concerning the relationships between subjects of the empire were still in existence, because 'even after claiming and obtaining their internal and external independence', the newly created states 'continued to cultivate among one another relations still based on the same rules as existed when the pope and the emperor were authorities superordinated over the other powers. ${ }^{25}$ Westphalia was not a moment of creation of a new legal order, but rather one in which 'the legal order of the ancient Holy Roman Empire' was 'limited in its jurisdiction solely to international matters because of the formation of modern states', and transformed to cater for the reluctance of modern states 'to admit in any field whatsoever a power superior to them. ${ }^{26}$

Of course, it is theoretically possible to conceive of all struggles of contemporary international lawyers as footnotes on the historical arc created by the end of the empire. ${ }^{27}$ During the Renaissance, says Sereni, the Holy Roman Empire, still technically sovereign over Italian cities, but in fact more and more devoid of power, was fetishized by writers as 'a messianic dream, an ideal aspiration' which had little to do with reality. ${ }^{28}$ As a divertissement, these words should perhaps

\footnotetext{
${ }^{21}$ Sereni, above n 6, 60 .

22 Ibid, 61.

23 Ibid, 119.

${ }^{24}$ G Balladore Pallieri, 'Le dottrine di Hans Kelsen e il problema dei rapporti tra diritto interno e diritto internazionale', (1935) 27 Riv Dir Int 24, 68 (Sereni’s translation).

${ }^{25}$ Ibid, 68-9 (Sereni's translation).

${ }^{26}$ Ibid.

${ }^{27}$ See e.g. W G Grewe, The Epochs of International Law (English edn, 2000), 51-60 and 141-62.

${ }^{28}$ Sereni, above n 6, 60 .
} 
inspire caution in keen cosmopolitan technocrats of today, who are also fetishizing the 'international community' as a unifying aspiration while they are busy managing the daily relations between international actors. But from a historiographical point of view, Sereni's approach is both flawed and drearily Eurocentric. First, there is an obvious risk of juxtaposing entirely different situations by imposing present concepts to a distorted view of the past. Second, even taking Sereni's approach seriously, the most interesting aspect of Bartolus' work, at least for our purposes, would not be the one concerning the internal dealings within the Empire, but the one concerning the relationship between the Holy Roman Empire and other peoples, classified by Bartolus as the Christian allies ('the Greeks'), the non-Christian friends ('the Tartars'), the permanent enemies ('the Turks'), and those ('the Indians') with whom 'non habemus pacem nec guerram, nec aliquid facere. ${ }^{29}$ Did Bartolus provide us with a specifically 'Italian' conception of dealing with them? Not really-his Roman law approach and his Latin prose were the European standard for the time, and Sereni's passionate defence thereof (comparing Bartolus to artists such as Michelangelo, Mantegna and Bramante) somewhat misses the mark. Sereni is forced to admit that it was only later that international law acquired distinct content and autonomous characteristics of its own. ${ }^{30}$ That is precisely the point.

Sereni is much more persuasive in his description of Renaissance Italy as a laboratory of international practice. Between the late $13^{\text {th }}$ and the $16^{\text {th }}$ centuries, the Italian states were at the centre of a very advanced and complex web of commerce, art and enterprise. Their relations with each other and with overseas countries, as well as the methods through which they settled international disputes, often amounted to the first legal scaffolding of contemporary international law. ${ }^{31}$ Indeed, Sereni is correct in pointing out that 'some international institutions that still exist, such as legations, consulates, extradition, and international settlements, are related to institutions which originated or at least reached their full development in Renaissance Italy.' ${ }^{32}$ But this is not a contribution in terms of an Italian 'conception' of international law, rather the building blocks of crucial aspects of the whole of international law.

Furthermore, modern international law still had to be born as a discipline. Fertile ground was to be found in 'proud Protestant sixteenth-century England,

\footnotetext{
${ }^{29} \mathrm{Ibid}, 61-2$ ('we have no peace nor war, nor we do anything at all').

${ }^{30} \mathrm{Ibid}, 62$.

${ }^{31}$ Ibid, 10-55.

${ }^{32}$ Ibid, 118.
} 
freed from all subordination to the emperor and the pope, ${ }^{33}$ where Alberico Gentili (1552-1608), an Italian Protestant persecuted by the Inquisition, found refuge. Gentili became the first Italian lawyer tenured at Oxbridge, and a very successful practitioner advising the English government as well as the Spanish embassy on matters of international law. But, leaving aside all issues concerning the relationship between Gentili and Grotius, the question here is whether we can really appropriate Gentili on behalf of an 'Italian' conception of international law. Given that he wrote in Oxford and that his books were in Latin, a nationalist appropriation of his work would be as wrong on behalf of Italy as it would on behalf of the United Kingdom. Gentili is certainly one of the main starting points of the construction of the European language of international law-not British doctrine, nor an Italian conception. ${ }^{34}$

Nor can we find a better candidate for Italian appropriation in Pierino Belli from Alba (1502-1575), whose De re militari et bello tractatus (A treatise on military matters and warfare $)^{35}$ was somewhat ahead of his time, especially in light of certain 'humanitarian' considerations contained therein. ${ }^{36}$ As Cavaglieri remarked, Belli was held in contempt by Gentili, who went very close to plagiarising Belli's work without even acknowledging his existence. ${ }^{37}$ Sereni praises Belli's 'breadth of ideas [that were] truly exceptional for his times' and his 'lofty' idealism. ${ }^{38}$ For Sereni, Belli was 'the last great writer of the Italian theologico-religious tradition'-that is, a natural lawyer. ${ }^{39}$ A Catholic writer quite at ease with the Spanish theological school of Vitoria and Suarez, Belli had long served in the Spanish military. Once again, assigning him exclusively to an 'Italian tradition' would be rather preposterous. As a natural lawyer, he was one of the earliest representatives of a certain mode of international legal thinking which was later to be eradicated by legal positivists. But before the 'magnificent and progressive fate' of positivism could take hold, Risorgimento had to occur, with its nationalist political theories still imbibed of natural law.

\footnotetext{
${ }^{33}$ Ibid, 105.

${ }^{34}$ For a recent assessment of his legacy, see B Kingsbury \& B Straumann (eds), The Roman Foundations of the Law of Nations: Alberico Gentili and the Justice of Empire (2010).

${ }^{35}$ Pierino Belli of Alba, De re militari et bello tractatus (1563), vol I (photostatic reproduction, 1936).

${ }^{36}$ See R Comba \& G S Pene Vidari (eds), Un giurista tra principi e sovrani: Pietrino Belli a 500 anni dalla nascita (atti del convegno di studi, Alba, 30 novembre 2002) (2004).

${ }^{37}$ A Cavaglieri, 'Introduction', in Pierino Belli of Alba, De re militari et bello tractatus (1563), vol II (1936 translation), 11a-28a.

${ }^{38}$ Sereni, above n 6, 99.

${ }^{39}$ Ibid, 97.
} 


\subsection{The Risorgimento and the theory of nationalities}

Sereni charitably jumps, in the space of a few pages, from the $16^{\text {th }}$ to the $19^{\text {th }}$ century. This period of 'decline of international law in Italy' coincided with the long decline of the small Italian Renaissance states faced with the military and economic competition of the ascending European monarchies. In that period, Italy became little more than a crucial battleground in Europe's eternal pursuit of a balance of power, and Italian international lawyers had very little to contribute compared to their non-Italian colleagues such as Zouche, Pufendorf, Wolff, Vattel or G F de Martens. ${ }^{40}$

The situation radically changed in the $19^{\text {th }}$ century. At the foundation of the Institut de droit international in 1873, Italian theories were very well known in European circles. Pasquale Stanislao Mancini (1817-1888) was the first president of the Institut and a prominent politician of the new Kingdom of Italy, of which he was the Foreign Minister between 1881 and $1885 .{ }^{41}$ His theory of nationalities, which he first formulated in the 1850s, gave an international legal dimension to Giuseppe Mazzini's political project of Italian liberation from foreign domination. A refugee from the Kingdom of the Two Sicilies to Piedmont, Mancini developed his theory along certain basic premises which well reflected the spirit of the times.

Echoing the earlier Neapolitan philosopher Giambattista Vico (1668-1744), Mancini held that nations were the basic units of human organisation. ${ }^{42}$ Not only did he argue that every nation 'should constitute one state and one alone', he further argued that a nation should be 'left free to organise itself as an independent state' according to the 'principle of the self-determination of the peoples'; that nations should be equal, and so should the states deriving therefrom; that arbitration should be compulsory; and that a legal order capable of settling disputes among nations should be established. Finally, Mancini stated that the pope should not be a territorial sovereign. ${ }^{43}$ These principles were further developed by a number of Italian international lawyers, such as Terenzio Mamiani (1798-1885) and Pasquale Fiore (1837-1914). Indeed, Fiore's natural law approach

\footnotetext{
${ }^{40}$ Ibid, $127-48$.

${ }^{41}$ On Mancini in general, see E Jayme, Pasquale Stanislao Mancini: internationales Privatrecht zwischen Risorgimento und praktischer Jurisprudenz (1980); C Storti, 'Mancini, Pasquale Stanislao', in I Birocchi et al (eds), Dizionario biografico dei giuristi italiani (XII - XX secolo) (2013) 1244.

${ }^{42}$ See generally his 1851 opening lecture at the University of Turin: P S Mancini, 'Della nazionalità come fondamento del diritto delle genti', in A Pierantoni (ed) Diritto internationale: prelezioni (1873) 1.

${ }^{43}$ Sereni, above n 6, 163-4.
} 
made him very well known outside Italy. ${ }^{44}$

The political nature of the nationalities doctrine determined both its fortune and its fate. 'Nation' is a most elusive concept-and a dangerous one at that. One of the purposes of Sereni's 1943 book was to disentangle the Italian doctrine of nationalities from the Italian racist laws of 1938 and from the 'absurd German theories' which Fascist Italy adopted because of its 'spirit of servility towards Germany. ${ }^{45}$ Indeed, the declared aim of Sereni's book was to persuade his Anglo-American audience that Fascism and Nazism had no influence on the Italian conception of international law. ${ }^{46}$ And yet, it is worth going back to Mancini's opening lecture at the University of Turin, in 1851, when he first expounded his theory of nationalities. The following passage on race, ignored by Sereni, indisputably contains the very Italian seeds of those 'German' absurdities:

Race, which expresses an identity of origin and blood, is another important constitutive element of the Nation. Precisely in this relationship the Nation takes from the Family. After Linnaeus' initiative, man's natural history became the subject of insightful studies, thanks to which anthropology can now declare to have gained this truth, that among men there is an evident plurality of races with more or less distinct characters, the furthest apart being the white and the [black], without them going outside the limits of natural varieties of an original and unique species. Where more than one race co-habited or violently juxtaposed on the same territory, there was no establishment of one Nationality, nor there could be if not after a slow fusion of the ones with the others, the mutual absorption of reciprocal qualities, and thus the formation of a new composite race. [...When considering ancient descriptions of racial characteristics of European peoples...], we are forced to believe in the durable persistence of certain transmissible characteristics of race, which must certainly affect the national spirit. It is this self-substratum, this foundation of physical and moral characteristics that are in common with one's brothers, that men usually love of the race they were born into: and it is this greater analogy of feelings and trends which establishes a stronger

\footnotetext{
${ }^{44}$ Ibid, 171-2.

45 Ibid, 176.

${ }^{46}$ Ibid, vii-viii (and see below).
} 
tie between individuals of the same stock in comparison to those who are alien therefrom. ${ }^{47}$

Despite these odious words, Mancini does not equate nationality and race, as Nazi theories would later do. A theory of nationality could exist even independently of racial considerations. ${ }^{48}$ Mancini's conception is shaped by multiple 'factors of nationality', such as history, customs, laws, religion, territory and language, with race being only one of these. For Mancini, a 'consciousness of nationality' is the essential element binding all of these factors together, so that a nation is, ultimately, what an organised people believe it is. ${ }^{49}$ But this slightly more nuanced approach did not impede the later ideological use of the idea of 'nation' as a tool in the intellectual arsenal of abhorrent supremacist doctrines. Furthermore, from the point of view of the doctrine of international law, the theory of nationalities was actually unworkable as the organisational criterion of a world community dominated by states, some of which were (and still are) pluri-national. ${ }^{50}$ Stating that nations and states must coincide would obviously lead to a constant state of war. But there is also a positive aspect to the theory of nationality. Its most important legacy is the subsequent development of the principle of self-determination of peoples, which would find its zenith after the Second World War. ${ }^{51}$

At the outset, the theory of nationalities had been very successful because of its resonance with the project of national unification. ${ }^{52}$ It was only natural, as Sereni remarks, that it would all but disappear once the Italian state came of age. $^{53}$ In this regard, a somewhat ironic twist ensued. Mancini, the architect

\footnotetext{
${ }^{47}$ Mancini, above $n$ 42, 31-3.

${ }^{48}$ For a criticism of the German mythology of race from the point of view of another theory of nationalities, see A Messineo, 'Gli elementi costitutivi della nazione e la razza', (1938) 89 III-2115 Civiltà Cattolica 209, one of the isolated examples of strong official criticism by the Catholic church at the time of the adoption of racial laws by Fascist Italy.

${ }^{49}$ Sereni, above n 6, 162.

${ }^{50}$ In this regard, it is interesting to note that the current Constitution of Bolivia, entered into force in 2009, defines the state of Bolivia as a 'Pluri-national' entity.

${ }^{51}$ For a detailed assessment of the Italian theory of nationalities (also) in this light see L Nuzzo, Origini di una scienza: diritto internazionale e colonialismo nel XIX secolo (2012), 87-168; on the link between the theory of nationalities and self-determination, see also A Cobban, The Nation State and National Self-Determination (rev. edn, 1969).

${ }^{52}$ For a complete history of the Italian school of nationalities, see E Catellani, 'Les maitres de l'École italienne du droit international au XIXe siècle', (1934) 46 RdC 705.

${ }^{53}$ Sereni, above n 6, 174 (the doctrine 'wore itself out toward the end of the century when the Risorgimento was well-nigh accomplished').
} 
of the principle of self-determination, concluded his career as Foreign Minister of the Kingdom of Italy, presiding over the first colonial efforts of the newly constituted nation. ${ }^{54} \mathrm{He}$ was thus forced to defend himself in Parliament against those accusing him of clearly contradicting his professed views on the right of peoples to be free. ${ }^{55}$ A shrewd politician, Mancini had realised that times had changed, and his protestations of coherence appeared rather unpersuasive. ${ }^{56}$ His incongruous turn to colonialism perfectly symbolises the Italian transformation from a people needing liberation from Austro-Hungarians, Bourbons and popes to the European Great Power, eager to share in the booty of a renewed 'civilizing mission'.

As far as international law was concerned, Guido Fusinato's (1860-1913) eventual admission that states, not nations, were the formal subjects of the international legal order was the final attempt of the Italian school of nationalities to reconcile with international practice. ${ }^{57}$ By then, natural law was soon to definitely give way to legal positivism, whose cloak of ostensible neutrality was much better suited to the new foreign policy of the Italian Kingdom.

\subsection{Anzilotti's eternal dominance}

\subsubsection{Fifty shades of black}

From the early $20^{\text {th }}$ century onwards, international legal scholarship in Italy could be described as a battleground between various shades of legal positivism. No neo-natural lawyer, no realist apologist of power, no Marxist, no poststructuralist, feminist or critical legal scholar has come to dominate the intellectual arena of Italian international law. If the 'Italian school' had to be reduced to one person to whom almost every prominent scholar was intellectually indebted, this person would undoubtedly be Dionisio Anzilotti (1867-1950). ${ }^{58}$ Although the debate has, at times, strayed from his strictest positions, especially in the case of the followers of Santi Romano (1875-1947) and Balladore Pallieri (1905-1980), the

\footnotetext{
54 T Scovazzi, 'Pasquale Stanislao Mancini e la teoria italiana del colonialismo', (1995) 78(3) Riv Dir Int 677 .

55 Ibid.

56 Ibid.

${ }^{57}$ Sereni, above n 6, 173-4.

${ }^{58}$ See inter alia: D Alland, Anzilotti et le droit international public (2012); L Passero, Dionisio Anzilotti e la dottrina internazionalistica tra Otto e Novecento (2010); F Salerno, 'L'affermazione del positivismo giuridico nella scuola internazionalista italiana: il ruolo di Anzilotti e Perassi', (2012) 95(1) Riv Dir Int 29.
} 
mainstream of Italian international legal academia never abandoned the linguistic perimeter of 'black letter' law which Anzilotti defined at the beginning of the last century. ${ }^{59}$ There are, of course, exceptions, such as Gabriele Salvioli's (1891-1979) Catholic natural law approach or Mario Giuliano's (1914-1988) Marxist outlook, ${ }^{60}$ but these are so sparse as to confirm the general trend.

Obviously, stating that the Italian school is both 'positivist' and 'dualist' on account of its founder may well be true and not leave us any wiser. As Gaja remarked in 1992, 'many possible meanings may be attached to the view that an international lawyer is a positivist and a dualist'. ${ }^{61}$ Rather than accounting for all the possible variants of positivism or mapping the many sub-schools in which the Italian school is in fact articulated, ${ }^{62}$ the purpose of this section is to consider two general points. First, can we identify some unifying factors in Italian international legal scholarship since Anzilotti? Second, do these factors make the Italian school in any way distinctive or separate from the classic 'black letter' side of the European legal tradition?

\subsubsection{The creation of the modern Italian school}

Many have remarked that Georg Jellinek (1851-1911) colourfully chastised late $19^{\text {th }}$ century international lawyers for being the last indulgers in the 'orgies' of natural law in an age of widespread codification of private and criminal law. ${ }^{63}$ Dionisio Anzilotti took it upon himself to rescue the Italian school of international law both from the politicised endeavours of Mancini and from the naturalism of Fiore. ${ }^{64}$ Crucially, Anzilotti's project was also directed at rejecting Hegelian and Austinian conceptions, negating any possibility of law among states because of the lack of a conceivable authority superior to them. ${ }^{65}$ In this regard (and perhaps in

\footnotetext{
${ }^{59}$ I use the term 'black letter' with the same neutral (or even positive) connotation with which it is employed by E Lauterpacht, 'Foreword', (2012) 1 CJICL 1.

${ }^{60}$ See generally G Salvioli, 'Les règles générales de la paix', (1933) 46 RdC 1.

${ }^{61}$ G Gaja, 'Positivism and Dualism in Dionisio Anzilotti', (1992) 3 EJIL 123, 123.

${ }^{62}$ Such an exercise was recently undertaken by the 'doyen' of Italian international lawyers: Ziccardi, above $\mathrm{n} 2$.

${ }^{63}$ G Jellinek, System der subjektiven öffentlichen Rechte (1892), 297, quoted in Alland, above n 58, 39; Passero, above n 58, 178; Sereni, above n 6, 210.

${ }^{64}$ See especially D Anzilotti, Teoria generale della responsabilità dello stato nel diritto internazionale (1902); D Anzilotti, Corso di diritto internazionale, vol I (4th edn, 1955); D Anzilotti, Scritti di diritto internazionale pubblico, vol II part 1 (1956).

${ }^{65}$ Alland, above n 58, 45-58.
} 
this regard only), we could put him in the same camp as the much more idealistic Hersch Lauterpacht (1897-1960). ${ }^{66}$

Anzilotti's project was perfectly in line with the evolution of the study of law in Italian universities at the time, under the combined influence of German and French doctrines. ${ }^{67}$ As Sereni put it, it was necessary to establish once and for all that 'the Italian science of law [was] separate from politics, religion, morals and the wishful thinking of well-meaning professors. ${ }^{\text {'68 }}$ This science had, as its object of study, the lex lata, which was composed of the legal rules which are actually observed by the states in their relations, organised into a system of 'basic principles' derived from those rules. ${ }^{69}$ Gaja has closely analysed how Anzilotti's thinking evolved over the years with respect to basic questions such as the nature of the international legal system (his was a voluntarist approach, including the notion of customary international law as a form of tacit agreement) and the relationship between domestic and international law, often considered a model of dualism. ${ }^{70}$ The latter was to become one of the most enduring legacies of his theory within the Italian school. ${ }^{71}$

However, the crucial point is that Anzilotti imported to Italy the teachings of Heinrich Triepel (1868-1946) and other German public law theorists. ${ }^{72}$ While recent studies have underlined that this process of translation was heavily influenced by Italian juridical culture, ${ }^{73}$ it is particularly telling that such a mediation occurred through the theories of Santi Romano, ${ }^{74}$ who had in turn been deeply influenced by French 'institutional' theorists, Maurice Hauriou

\footnotetext{
${ }^{66} \mathrm{H}$ Lauterpacht, The Function of Law in the International Community (1933).

${ }^{67}$ See P Grossi, Scienza giuridica italiana: un profilo storico 1860-1950 (2000), 83. An important influence on Anzilotti was his contemporary, Donato Donati (1880-1946), a constitutional law and public international law scholar, whose works were among the first in Italy to adopt a positivist outlook in international law: see e.g. D Donati, I trattati internazionali nel diritto costituzionale (1906). Donati was also very influential on Rolando Quadri and other subsequent Italian scholars.

${ }^{68}$ Sereni, above n 6, 277.

${ }^{69}$ Ibid, 212.

${ }^{70}$ Gaja, above $n 61$.

${ }^{71}$ On the fortune of dualism in the Italian school, see G Gaja, 'Dualism-A Review', in JE Nijman \& A Nollkaemper (eds), New Perspectives on the Divide Between National and International Law (2007) 52.

72 See Passero, above n 58, 177-211, citing inter alia H Triepel, Völkerrecht und Landesrecht (1899).

${ }^{73}$ Salerno, above n 58.

${ }^{74}$ See in particular S Romano, L'ordinamento giuridico: Studi sul concetto, le fonti e i caratteri del diritto (1917), translated as S Romano, L'ordre juridique (2nd trans. edn, 2002); S Romano, Corso di diritto internazionale (4 edn, 1939).
} 
(1856-1929) in particular. ${ }^{75}$ These fertile debates between French and German theories were the building blocks of Italian juridical science in the $20^{\text {th }}$ century. ${ }^{76}$ A successful fusion of French and German theories was expressed by Tomaso Perassi (1886-1960), whose theory of sources influenced Anzilotti himself, as well as the Italian school more generally. ${ }^{77}$ For Sereni, it was important to underline that the reaction to Anzilotti's theories by Romano, Balladore Pallieri and Perassi had not in fact challenged the two fundamental objectives that Anzilotti had set out to achieve, namely to eradicate natural law and to affirm international law against realist apologists of power. Although fundamental to understanding how positivism evolved in Italy, the conflict between Anzilotti's and Romano's theories was 'actually one of degree rather than substance', because each of these authors 'accept [ed] the positivist method' ${ }^{78}$

And so did the other great masters born at the outset of the $20^{\text {th }}$ century. Among the most prominent successors of Anzilotti and Perassi in the Rome La Sapienza chair of international law, Gaetano Morelli (1900-1989) came to embody the Kelsenian and norm-oriented side of the positivist Italian school. ${ }^{79}$ The first Italian judge at the International Court of Justice (from 1961 to 1970), he devoted his academic career to issues of international procedure spanning across public and private international law. ${ }^{80}$ In this regard, it is worth mentioning that one of the many explaining factors of the Italian school's norm-oriented approach is that the teaching and research in private and public international law were joined in one single chair of 'international law', so that the two disciplines greatly influenced each other. International law was taught as an advanced technical subject involving the rigorous exegesis of text.

After Morelli, the next Italian to become a judge at International Court of Justice was Roberto Ago (1907-1995), to whose contribution we shall presently turn. From the same generation, Rolando Quadri (1907-1976) had a great influence in Italian legal academia spanning across both private and public international law. ${ }^{81}$ His 'monist' interpretation of Article 10(1) of the Italian

\footnotetext{
${ }^{75}$ Sereni, above n 6, 266-7.

${ }^{76}$ See generally Grossi, above $\mathrm{n} 67$.

${ }^{77}$ See Salerno, above n 58, 50-60.

${ }^{78}$ Sereni, above $\mathrm{n} 6,267-8$.

${ }^{79}$ On Morelli in general, see F Salerno (ed), Il ruolo del giudice internazionale nell'evoluzione del diritto internazionale e comunitario: atti del Convegno di Studi in memoria di Gaetano Morelli organizzato dal'Università di Reggio Calabria (Crotone 22-23 ottobre 1993) (1995).

${ }^{80}$ See G Morelli, 'Cours général de droit international public' (1956 I) 89 RdC 437; G Morelli, 'La théorie générale du procès international' (1937 III) $61 R d C 253$.

${ }^{81}$ See generally P De Sena, 'Quadri, Rolando', in Birocchi et al, above n 41, 1641.
} 
Constitution, to the effect that both treaties and customary international law would prevail over constitutional provisions by virtue of the pacta sunt servanda rule, was one of the very few departures from Anzilottian dualism in the Italian school. ${ }^{82}$ However, his overall construction remained a positivist one, albeit with a 'realistic' emphasis on international practice, ${ }^{83}$ which was later to be further developed by Paolo Picone (b. 1940). But it is now time to turn to Roberto Ago, the perfect example of how Anzilotti's successful doctrinal project brought the Italian school into the European positivist mainstream.

\subsubsection{An example: attribution of internationally wrongful conduct in Ago}

One of the defining features of Anzilotti's construction was an emphasis on rules on responsibility for internationally wrongful acts. A true legal system based on positive law must provide for certain consequences when rules are violated. It is, therefore, not accidental that responsibility became one of the areas in which the contribution of the Italian school has been most enduring throughout time, especially at the International Law Commission-thanks to the Special Rapporteurs Roberto Ago, Gaetano Arangio-Ruiz (b. 1919), and Giorgio Gaja (b. 1939). ${ }^{84}$ It is useful to consider whether this contribution, although certainly fundamental, can in fact be disentangled from its broader international context-and consequently whether it can be deemed 'Italian' in any meaningful way. I will use the example of Ago's proposals on the attribution of internationally wrongful conduct to states, which is just one small sub-set of the many issues concerning responsibility. ${ }^{85}$

As Ago put it in 1971, states only act through human beings, because 'the State, as a legal person, is not physically capable of conduct'. ${ }^{86}$ The same is true of international organisations and other collective entities. It follows that

\footnotetext{
${ }^{82}$ See Cannizzaro, above n 2, 5-8. It should be pointed out that this 'monist' system was ultimately relying on a domestic constitutional law provision to come into existence-even Italian 'monists' are formally dualists after all.

${ }^{83}$ See the last edition of his seminal textbook: R Quadri, Diritto internazionale pubblico (5th edn, 1968).

${ }^{84}$ See G Arangio-Ruiz, 'Fine prematura del ruolo preminente di studiosi italiani nel progetto di codificazione della responsabilità degli Stati: specie a proposito di crimini internazionali e dei poteri del Consiglio di Sicurezza', (1998) 81 Riv Dir Int 110; Cannizzaro, above n 2, 18-9.

${ }^{85}$ On Roberto Ago in general, see R Luzzatto, 'Ago, Roberto', in Birocchi et al, above n 41, 11. I will focus only on states here, but analogous considerations apply to international organisations and possibly other subjects of international law.

${ }^{86}$ R Ago, ‘Third report on State responsibility', ILC Ybk 1971/II(1) 199, 217.
} 
international law must be able to determine when a certain conduct can be attributed to a state, especially in the context of assigning responsibility for the breach of international obligations. The concept of attribution of conduct is a relatively recent one in the history of international law. The main reason for this is that international responsibility itself emerged quite late as a discrete subject of study. In his 1923 lectures on state responsibility at the Hague Academy of International Law, De Visscher started out by observing that it was not until Triepel and 'especially' Anzilotti's works, of about twenty years earlier, that state responsibility had started acquiring a theoretical framework. ${ }^{87}$ And it was not until shortly after De Visscher's lectures that Eagleton published his seminal monograph on the topic. ${ }^{88}$ In fact, Grotius and his Italian precursors Pierino Belli and Alberico Gentili had considered in passing the complex question of the responsibility of a sovereign for the wrongs of its citizens and vice versa. ${ }^{89}$ And some initial ideas on the consequences of pacta sunt servanda had been considered by Zouche, Pufendorf, Van Bynkershoek and Wolff in the $17^{\text {th }}$ and $18^{\text {th }}$ centuries. ${ }^{90}$ Furthermore, in his famous $19^{\text {th }}$ century work, Calvo addressed at some length the question of the responsibility of the government for the acts of its agents. ${ }^{91}$ Nonetheless, it was only in the $20^{\text {th }}$ century-with Triepel, Anzilotti, De Visscher, Eagleton and the 1928 Factory at Chorzów case before the Permanent Court of International Justice (to which Anzilotti clearly gave a significant contribution) ${ }^{92}$ - that international responsibility started its evolution from being at the margins of international legal discourse into being (one of) the best proof [s] of [the] existence and the most credible measure of [the] effectiveness' of international law, in line with Anzilotti's project. ${ }^{93}$

In the course of this evolution, the idea of 'imputability' or 'attribution' of acts and omissions to states always featured prominently. Anzilotti conceived

\footnotetext{
${ }^{87}$ C De Visscher, 'La responsabilité des États', in Bibliotheca Visseriana Dissertationum Ius Internationale Illustrantium vol 2 (1924) 86.

${ }^{88} \mathrm{C}$ Eagleton, The Responsibility of States in International Law (1928).

${ }^{89} \mathrm{~J}$ Crawford, T Grant \& F Messineo, 'Towards an International Law of Responsibility: Early Doctrine', in L Boisson de Chazournes \& M Kohen (eds), Liber Amicorum Vera Gowlland-Debbas (2010) 377, 377. On the history of international responsibility, see also I Brownlie, System of the Law of Nations: State Responsibility, Part I (1983), 1-9.

${ }^{90}$ Crawford, Grant \& Messineo, above n 89, 378.

${ }^{91}$ C Calvo, Le droit international théorique et pratique, vol III (5th edn, 1896) 120-35.

${ }^{92}$ Factory at Chorzów (Germany v. Poland) (Jurisdiction) (1927) PCIJ Ser A No 9; Factory at Chorzów (Germany v. Poland) (Merits) (1928) PCIJ Ser A No 17.

${ }^{93}$ A Pellet, 'The Definition of Responsibility in International Law', in J Crawford, A Pellet \& S Olleson (eds), The Law of International Responsibility (2010) 3, 3-6.
} 
what has become the classic account of attribution, according to which attributing a certain conduct to a state or an international organisation does not imply an assessment of the causes of a certain act, nor of the 'culpability' or 'intentions' of the state or international organisation-even if one accepted that an assessment of the volitions of abstract collective entities were at all possible. In Anzilotti's theory of international responsibility of 1902, attribution of conduct is described as the result of legal criteria, not sociological or psychological inquiries. ${ }^{94}$ It was, as he put it, 'a pure result of the law'. ${ }^{95}$ Crucially, for Anzilotti, negligence, culpa, or intentions of the human beings acting on behalf of the state were wholly irrelevant to the attribution of conduct to a state or an international organisation. ${ }^{96}$

This quintessentially positivist position was only one of the premises elaborated upon by Roberto Ago when he became the Special Rapporteur on State Responsibility at the International Law Commission. ${ }^{97}$ His first draft of the Articles on State Responsibility contained 11 separate provisions devoted to the attribution of conduct to states. These provisions were simplified and shortened in the final 2001 version of the Articles, ${ }^{98}$ which maintained, in substance, Ago's approach. ${ }^{99}$ Even a cursory reading of Ago's reports is sufficient to realise that his approach was not exclusively 'Italian' in any meaningful sense: the history of international responsibility may well have started with Anzilotti, but other influences were fundamental in Ago's construction. ${ }^{100}$ This means that what could possibly be considered the most enduring Italian contribution to the codification of public international law-rules on attribution of internationally wrong-

\footnotetext{
${ }^{94}$ See Anzilotti, Teoria generale, reprinted in Scritti, above n 64, 1, 121-148.

95 Anzilotti, Corso, above n 64, 222.

${ }^{96}$ Not everyone in the Italian school agreed with this separation of causality from attribution, especially when omissions are concerned: see e.g. B Conforti, 'Exploring the Strasbourg Case-Law: Reflections on State Responsibility for the Breach of Positive Obligations', in M Fitzmaurice \& D Sarooshi (eds), Issues of State Responsibility before International Judicial Institutions (2004) 129; G Arangio-Ruiz, 'State fault and the forms and degrees of international responsibility: questions of attribution and relevance', in M Virally (ed) Le droit international au service de la paix, de la justice et du développement: mélanges (1991) 25.

${ }^{97}$ See Draft Articles on State Responsibility Adopted on First Reading, ILC Ybk 1996/II(2), 58; R Ago, 'First report on State responsibility', ILC Ybk 1969/II, 125 and ILC Ybk 1971/II(1), 193; R Ago 'Second report on State responsibility', ILC Ybk 1970/II, 177; R Ago 'Third report on State responsibility', ILC Ybk 1971/II(1), 199; R Ago 'Fourth report on State responsibility', ILC Ybk 1972/II, 71.

${ }^{98}$ See Draft Articles on Responsibility of States for Internationally Wrongful Acts, ILC $Y b k$ 2001/II(2), 26; J Crawford, 'First report on State responsibility', ILC Ybk 1998/II(1), 1, 32 ff.

${ }^{99}$ See J Crawford, 'Revising the draft articles on state responsibility', (1999) 10 EJIL 435.

${ }^{100}$ On Ago's reports and their influence, see A Pellet, 'Les Rapports de Roberto Ago à la C.D.I. sur la Responsabilité des États', (2002) 4 Int'l L FORUM droit international 222.
} 
ful conduct-was not the product of some Italian distinctiveness, but rather of Anzilotti's successful internationalisation of the Italian school.

\subsection{The unintended consequences of legal positivism}

\subsubsection{The measure of Anzilotti's success}

The example of attribution of conduct should have clarified that Anzilotti's success in founding the Italian school of international law rendered it relatively indistinguishable from other European counterparts. By discarding Mancini’s national school and Fiore's natural law, Anzilotti transited Italian international legal scholarship into the mainstream of European legal thinking. This achievement was so profound that one may wonder whether it did not in fact have certain costs. At least two aspects should be considered: first, a form of indirect complacency with the Fascist Regime; and second, a certain lack of intellectual diversity within the Italian school, at least for the first part of the $20^{\text {th }}$ century. Both are rooted in an understanding of law and the legal method as 'neutral science'.

\subsubsection{The complex relationship with Fascism}

We have seen that Sereni's main aim in 1943 was to show that Fascism had had no impact on international legal scholarship in Italy. He devotes a whole chapter to disproving the existence of a fascist conception of international law, ${ }^{101}$ and clearly states in the preface that the book 'also has a political purpose', which is 'to show that a deeply rooted love for justice and freedom pervades the writings of all the greatest international lawyers of Italy' and that 'a silent but efficient resistance against fascist influence ... has been maintained by most of the Italian scholars. ${ }^{102}$ These words were written while the Second World War was still ongoing, and they come from an Italian who had to take refuge in the United States because of the racial laws introduced by the Italian regime. They must therefore be understood in their context, and with unbounded respect for their author. However, they also must be qualified. First, none of the Italian professors of international law refused to pledge allegiance to Mussolini's regime in 1931, when this was made a requirement for holding an academic position. ${ }^{103}$ Second, although the production of prominent Italian international lawyers was never couched in terms of adherence to a fascist international legal doctrine (which

\footnotetext{
${ }^{101}$ Sereni, above n 6, 269-78.

${ }^{102}$ Ibid, vii.

${ }^{103}$ Salerno, above n 2, 308-9.
} 
indeed never emerged as such in Italy), the actual record of the legal positions advanced by scholars at the time is rather problematic, even if it was couched in terms of formally positivist legal positions. ${ }^{104}$ In other words, it is possible to identify, from the mid-1930s onwards, 'a benevolent approach towards positions maintained by fascism, ${ }^{105}$ for example in relation to the war against Ethiopia (notably by Santi Romano and even by Sereni himself). ${ }^{106}$

While Anzilotti's positivist method somewhat shielded Italian international lawyers from the pressure of coming up with a fascist doctrine of international law, and allowed them to confidently retreat into very abstract questions, ${ }^{107}$ it also allowed politically unsavoury positions to be adopted with an aura of neutrality towards the regime. As had been the case before Fascism, ${ }^{108}$ when the patria called, legal arguments were clearly tailored to fit the position of the government and to defend Italy. In Bartolini's persuasive view, 'the screen apparently provided by positivism in analysing legal issues can hardly be said to be totally impermeable to political assessment.' ${ }^{\text {,9 }}$ Indeed, critical legal scholars would argue that such impermeability simply could not exist.

\subsubsection{The missing branches: Catholic and Marxist conceptions}

Another critique which may be levied at the solid positivist foundations laid down by Anzilotti is that they could only support a limited set of architectural choices. By enlisting Italian international law to the European mainstream, many possible competing narratives were lost, two of which will be considered here.

The first, and perhaps most obvious, concerns the influence of the Roman Catholic Church in international law. Catholicism was one of the dominant cultural forces in $20^{\text {th }}$ Italy, yet its conception of international law remained mostly outside the mainstream of scholarly production. We have seen that Gabriele Salvioli was an exception, ${ }^{110}$ but there were not many others. The writings of An-

\footnotetext{
${ }^{104} \mathrm{G}$ Bartolini, 'The Impact of Fascism on the Italian Doctrine of International Law', (2012) $14 \mathrm{~J} \mathrm{Hist}$ Int'L L 237.

${ }^{105}$ Ibid, 249.

${ }^{106}$ Ibid, 250-8; Salerno, above n 2, 311-2. On the complex lessons to draw from the 'Abyssinia crisis', see R Parfitt, 'Empire des Nègres Blancs: The Hybridity of International Personality and the Abyssinia Crisis of 1935-36', (2011) 24 Leiden J Int'l L 849.

${ }^{107}$ Sereni, above n 6, 277-8.

${ }^{108}$ See G Gaja, 'Le prime annate della "Rivista di diritto internazionale” ed il rinnovamento del metodo', (1987) 16 Quaderni Fiorentini per la storia del pensiero giuridico moderno 485, 491.

${ }^{109}$ Bartolini, above n 104, 283. A slightly more favourable reading of the autonomy of the Rivista di Diritto internazionale against Fascism is provided by Salerno, above n 2, 308-14 and 320-21.

${ }^{110}$ See generally Salvioli, above n 60.
} 
tonio Messineo (1897-1978), a Jesuit intellectual working at the influential magazine La Civiltà Cattolica, remained an isolated attempt at expounding a Catholic doctrine of international law. ${ }^{111}$ And while it is true that the official position of the Holy See is that natural law should be at the heart of the world's juridical order, even in the $21^{\text {st }}$ century, ${ }^{112}$ this position is definitely not shared by the majority of Italian scholars.

The fact that no Catholic doctrine of international law emerged from within the Italian school can perhaps be explained historically. Italian international law was born as a proudly secular enterprise. Mancini's position against the temporal power of the pope and his fervent anti-clerical speeches in Parliament ${ }^{13}$ were quite standard for a Risorgimento man: after all, Italy's unification project involved the invasion of the Papal States and the conquest of Rome. Anzilotti's later endeavours were explicitly directed at eradicating natural law, the Church's standard doctrine in matters of international law. What is more startling, however, is that the unfettered cultural presence of the Church throughout $20^{\text {th }}$ century Italy did not inspire a reconsideration of natural law principles within the Italian school of international law as one of the possible exit strategies from strict positivism-not even in a secularised form separated from the 'revealed truth' of religion. In other words, it is somewhat surprising that Italy did not produce its own equivalent of an international legal theorist such as Philip Allot, ${ }^{114}$ nor a humanist conception such as that of Antônio Augusto Cançado Trindade. ${ }^{115}$

It is equally startling that, despite the great cultural influence of the Italian Communist Party throughout the $20^{\text {th }}$ century, the Italian conception of international law was almost completely impermeable thereto. ${ }^{116}$ This may have to do with the Italian Communist Party's 'orthodox' Marxist approach. For the Party, international law was simply a bourgeois instrument of oppression benefiting the

\footnotetext{
${ }^{111}$ See A Messineo, Il diritto internazionale nella dottrina cattolica (2nd edn, 1944).

${ }^{112}$ See e.g. Holy See Press Office, 'The Rule of Law Requires a Legal System based on Natural Law', Vatican Information Service, 26 September 2012, <http://visnews-en.blogspot.nl/2012/09/therule-of-law-requires-legal-system.html> [accessed 23 July 2013].

${ }^{113}$ See an exemplary excerpt in Scovazzi, above n 54, 678.

${ }^{114}$ See e.g. P Allott, The Health of Nations: Society and Law beyond the State (2002).

${ }^{115}$ See e.g. A A Cançado Trindade, 'International Law for Humankind: Towards a New Jus Gentium', (2005) $316 R d C 13$ and (2005) $317 R d C 11$.

${ }^{116}$ The same overall conclusion was reached by F Francioni \& F Lenzerini, 'Reflections on the Impact of Communism on Italian International Law Scholarship: 1945-1989', EUI Working Papers, LAW 2009/23, 1 December 2009, <http://papers.ssrn.com/sol3/papers.cfm?abstract_id=1557682 > [accessed 23 July 2013].
} 
'imperialist warmonger side' of the Cold War. ${ }^{117}$ Yet, some international lawyers joined the Party, including Mario Giuliano (1914-1988), a very prominent member of Roberto Ago's school. ${ }^{118}$ But just as was the case with Ian Brownlie, who was a member of the Communist Party of Great Britain until 1968, ${ }^{119}$ this did not translate into an abandonment of the positivist method. Cassese explicitly laments that Giuliano's scholarly production ends up following 'the most traditional style of the Italian school' except for some conclusions concerning international law as superstructure. ${ }^{120}$ Of course, there were some exceptions in more recent times, such as Aldo Bernardini (b. 1935), whose conception of international law is explicitly critical of 'bourgeois' positivism. ${ }^{121}$ But, overall, in the country of Antonio Gramsci, legal positivism was so hegemonic that no counter-hegemony even came close to emerging amongst international lawyers. ${ }^{122}$ This is in stark contrast with persisting Marxist legacies in other international legal circles, ${ }^{123}$ as well as in Italian culture more generally.

\subsection{The more recent heresies of pragmatic utopians}

The rather sobering conclusion reached so far is that the successful creation of an Italian school of international law led to its loss of distinctiveness compared to Mancini's 'theory of nationalities'. The more Anzilotti's project became successful, the more Italians were effectively joining the European mainstream of legal positivism-what we may call 'black letter law'-as the legal method of choice. Given the well-known hierarchical structure of Italian academia, it is not surprising that little space was left for outsiders. But a word of caution is needed. The broad strokes I have painted above do not take into account the most recent developments in Italian scholarship in international law. There appears to be more interest towards theoretical, historical and critical approaches to the discipline today than ever before. These 'heresies' from Anzilottian rigour

\footnotetext{
${ }^{117}$ S Segre, 'Il diritto internazionale come scienza di classe al servizio dell'imperialismo' (1949) 6:(10) Rinascita 421.

${ }^{118}$ Cassese, above n 13, 118. See M Giuliano, La comunità internazionale e il diritto (1950).

${ }^{119}$ M Childs, 'Sir Ian Brownlie: International lawyer who fought for human rights and civil liberties', The Independent, 25 February 2010, <http://www.independent.co.uk/news/obituaries/sir-ian-brownlie-international-lawyer-who-fought-for-human-rights-and-civil-liberties1909491.html> [accessed 23 July 2013].

${ }^{120}$ Cassese, above n 13, 119.

${ }^{121}$ A Bernardini, 'Diritto internazionale', in G Crifò (ed) Diritto (1972) 172.

${ }^{122}$ A point made also by Bernardini himself: ibid, 173. See also Francioni \& Lenzerini, above n 116, $17-22$.

${ }^{123}$ See generally S Marks (ed), International Law on the Left: Re-examining Marxist Legacies (2008).
} 
are part of the rising theoretical movement in international law more generally. Once again, Italian international lawyers are gregarious members of the 'Invisible College', and this College is finally becoming more diverse.

Some would argue that these developments have long been brewing. A certain departure from strict positivism had already been noticed by Antonio Cassese (1937-2011) in a short historical note published in 1990. ${ }^{124}$ From the 1960s onwards, he argued, the 'monolithic' methods of Italian international law began to 'crumble.' ${ }^{125}$ New trends emerged within positivism, such as the 'decline of formalism' in favour of a renewed attention to practical and contemporary problems; ${ }^{126}$ a slightly more open mind towards normative, rather than descriptive, projects, with renewed attention to the practice of states; ${ }^{127}$ and an interest towards the history of the discipline. ${ }^{128}$ In Cassese's view, all of these elements led to a much more varied landscape, in which prominent scholars such as Benedetto Conforti (b. 1930) and Luigi Condorelli (b. 1938) emerged as enlightened (or critical) positivists, well versed with the reality of the application of legal norms in domestic legal orders. ${ }^{129}$ The roots of this change were indeed already contained in the above-mentioned 'realist' outlook of Rolando Quadri and Paolo Picone. But it is not unfair to note that these scholars were all fully committed to 'legal methodology' and a 'strict distinction between de lege lata enquiries and de lege ferenda proposals.' ${ }^{\text {' }}$

Because of these developments, things have certainly changed in Italian legal scholarship since Anzilotti. ${ }^{131}$ In fact, Cassese himself was one of the most prominent international lawyers of his time, and he came to embody a certain mode of thinking about international law, as far removed from strict positivism as it was possible to be while still 'playing the game', i.e. remaining inside the linguistic parameters of positive international law. In a rather self-effacing account of his career written three years before his death, he described his academic beginnings as those of a torn young scholar forcing himself to be 'a strict legalist' despite his real 'desires and tendencies. ${ }^{132}$ He soon became aware

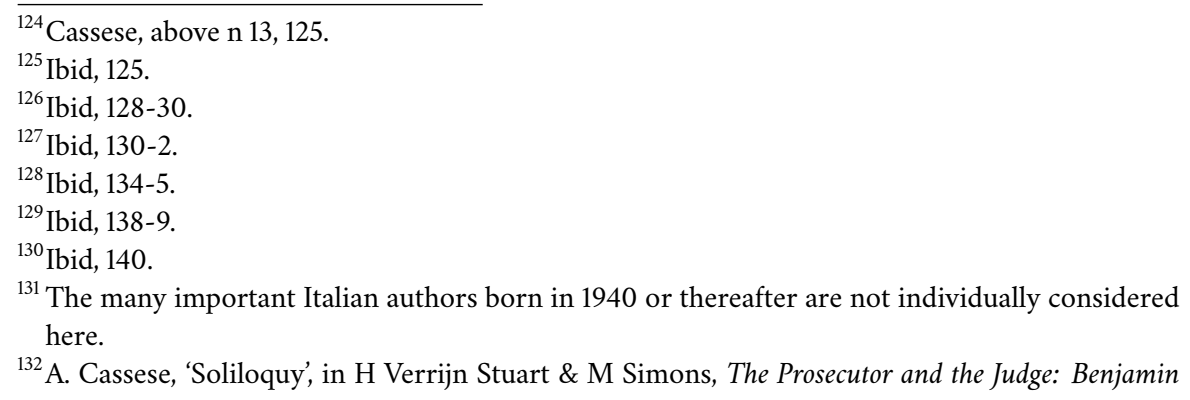


that while positivism had the advantage of clarifying the distinction between law and history or politics, therefore enabling lawyers to 'keep politics at bay', such a distinction could lead to inadvertent subservience towards power, as had happened during Fascism. ${ }^{133}$ Furthermore, positivism constituted a 'powerful shield of state sovereignty. ${ }^{134}$ In his view, it was necessary to move beyond the strict parameters agreed upon by States when 'the need to oppose glaring injustice' exceptionally required one to do so. ${ }^{135}$ Law was not to be a world of abstract Platonic ideas, and lawyers should engage in a 'strict and rigorous legal method' to understand legal institutions and in a more general analysis of the 'political, social or economic motivations' leading to those institutions, never shying away from suggesting how the law should be changed. ${ }^{136}$

The last collection of essays Cassese edited, published posthumously and appropriately named Realizing Utopia, opened with his remarks on international law's need for 'judicious reformers', a label he borrowed from Aldous Huxley to identify those who are neither utopians, nor disillusioned technicians. ${ }^{137}$ And yet, the positive method was never completely abandoned by Italian international lawyers, not even by Cassese. Some would argue that his constant analysis of the lex lata from the point of view of what the law ought to be occasionally led to a form of wishful legal thinking-not unlike previous idealist-but-positivist international lawyers such as Hersch Lauterpacht. But Cassese's utopias, like Lauterpacht's, were always quite pragmatic: the revolution was to be dressed in the same language states had chosen to bind themselves to, otherwise it would never become effective.

\section{The flaws of a comparative approach to international law}

There is nothing especially 'Italian' about this tension between the many possible shades of black letter law, from pitch dark to dark grey: this is the same debate international lawyers have had throughout the $20^{\text {th }}$ century and beyond. But this lack of distinctiveness of the Italian school is not worrisome in itself. The most

\footnotetext{
Ferencz and Antonio Cassese, Interviews and Writings (2009), 144.

${ }^{133}$ Ibid, 146.

${ }^{134}$ Ibid.

${ }^{135}$ Ibid, 147.

${ }^{136}$ Ibid, 149.

${ }^{137}$ A Cassese (ed), Realizing Utopia: the Future of International Law (2012), xvii-xviii.
} 
radical criticism that could be levied to Sereni's book of 1943 is that there is no particular need for an Italian conception of international law. Of course, analysing whether different legal traditions can influence our perception of international legal problems may be interesting, precisely in order to avoid parochialism.

Focarelli argues that international law should be remythologized by investigating all the legal traditions known in comparative legal analysis, rather than on (Western) jurisprudential grounds, and its reality in the sphere of communication. ${ }^{138}$ Indeed, a comparative approach serves to protect the diversity of international legal cultures, as Judge Yusuf argues elsewhere in this issue. This is a rather different project from that of defending the national pride of a community of scholars, as Sereni arguably set out to do. But is an emphasis on this 'comparative' perspective fruitful? Paradoxically, one of the key insights of 'comparative international law' seems to be that engaging in 'comparative international law' may not always be a good idea. National schools may well exist, but talking in these terms invariably risks silencing dissenting voices and reinforcing the scholarly positions of the majority. This is especially true in a Continental European context, where disproportionate respect towards the academic authority of old and current masters often asphyxiates the creation of new ideas. ${ }^{139}$ In contrast, in those contexts where originality is more emphasised (at times overzealously so), the very process of identifying a 'legal tradition' may well become impossible:

For instance, it has always been exceedingly difficult to say whether America has a national tradition in international law. To illustrate, who in the American legal academy could summarize the main tenets of the American approach to international law? Even assuming such a brave step were taken, for every such enunciation by, say, Anne-Marie Slaughter or W. Michael Reisman, one could point to a countervailing summation by, say, Jack Goldsmith or David Kennedy. The point is, within the American society of international law scholars, there are a sufficient number of diametrically opposed positions that it becomes impossible to brand one position dominant or orthodox. ${ }^{140}$

\footnotetext{
${ }^{138}$ C Focarelli, International Law as Social Construct: The Struggle for Global Justice (2012), 140.

${ }^{139}$ See H Ruiz Fabri, 'Reflections on the Necessity of Regional Approaches to International Law Through the Prism of the European Example: Neither Yes nor No, Neither Black nor White, (2011) 1 Asian J Int'l L 83.

${ }^{140}$ Mamlyuk and Mattei, above n 1, 428.
} 
In fact, there are possibly as many Italian conceptions of international law as there are scholars with Italian passports, in Italy and abroad. While there is no uniquely Italian conception of international law, there certainly is an Italian school in the broadest sense: that is the community of practice of those 268 academics and their Italian colleagues abroad, who in large part (but no longer exclusively) follow the European mainstream of norm-oriented, or positivist, international law. Future studies of this community of practice would need to consider certain sociological aspects which were not dealt with in Sereni's book of 1943, nor that could be dealt with here. For instance, analysing the reciprocal influence of academic international law and Italian diplomatic practice may shed some light on whether Italian international lawyers have still sometimes been tempted to cast a benevolent eye on legal positions helpful to Italian foreign policy, following the example of Mancini's about-turn from self-determination to colonisation. 